\title{
Parenting satisfaction of dual earner couples in child rearing stage of family life cycle
}

\author{
RUCHI GALUNDIA
}

Received: 26.01.2015; Revised: 10.04.2015; Accepted: 25.04.2015

Author for correspondence: RUCHI GALUNDIA College of Home Science, Maharana Pratap University of Agriculture and Technology, UDAIPUR (RAJASTHAN) INDIA
ABSTRACT : The traditional Indian system is being profoundly shaken and the women life style is being re-written because of numerous forces. Literacy and employment rates have increased significantly for the women. Due to this, more and more women are now seeking employment outside their home and formation of nuclear type family is commonly seen. The parental role is one of the most important roles in adulthood. The present study focused on the comparison of parenting satisfaction in joint and nuclear families in child rearing stage of family life cycle. The sample comprised of 60 dual earner couples ( 30 couples from joint families and 30 couples from nuclear families) selected randomly from Udaipur district in Rajasthan state. A selfconstructed parenting satisfaction inventory was used for collecting the data. Results showed that there was significant difference between parenting satisfaction of dual earner couples in joint and nuclear families. Couples in joint families were highly satisfied with all the aspects of child care such as feeding, bathing, toilet training, dressing, rest and sleep, tasks related with motor skills, socio-emotional behavior of infant and verbal cognitive competence of infant as compared to couples in nuclear families.

KEY WORDS: Parenting satisfaction, Dual earner couples, Joint family, Nuclear family

- HOW TO CITE THIS PAPER: Galundia, Ruchi (2015). Parenting satisfaction of dual earner couples in child rearing stage of family life cycle. Asian J. Home Sci., 10 (1) : 149-154. 